\title{
Biological Control of Leaf Spot and Growth Promotion of Eucalyptus Plants by Trichoderma spp.
}

\author{
Magno Rodrigues Carvalho Filho ${ }^{1}$, Irene Martins ${ }^{1}$, Gustavo Henrique Silva Peixoto ${ }^{2}$, \\ Paulo Henrique Pereira Costa Muniz ${ }^{2}$, Daniel Diego Costa Carvalho ${ }^{2} \&$ Sueli Corrêa Marques de Mello ${ }^{1}$ \\ ${ }^{1}$ Embrapa Recursos Genéticos e Biotecnologia, Brasília, Distrito Federal, Brazil \\ ${ }^{2}$ Universidade Estadual de Goiás, Ipameri, Goiás, Brazil \\ Correspondence: Sueli Corrêa Marques de Mello, Embrapa Recursos Genéticos e Biotecnologia, Parque Estação \\ Biológica W5 Norte, Asa Norte, 70770-900, Brasilia, Distrito Federal, Brazil. Tel: 55-61-3448-4433. E-mail: \\ sueli.mello@embrapa.br
}

Received: May 28, 2018

Accepted: June 29, 2018

Online Published: August 15, 2018

doi:10.5539/jas.v10n9p459

URL: https://doi.org/10.5539/jas.v10n9p459

\begin{abstract}
This study aimed to evaluate the potential of twelve Trichoderma isolates on eucalyptus leaf spot control induced by Cylindrocladium scoparium and determine the sporulation capacity of the isolates on two substrates (parboiled rice and millet) for selection of potential biocontrol and growth promoter agents, in eucalypt seedlings. In the in vitro experiments, volatile and non-volatile metabolites tests showed different levels of inhibition of the pathogen mycelial growth. In tests on detached leaves, it was observed suppression of disease symptoms with all Trichoderma strains in leaves inoculated with CEN494 isolate of the pathogen, whereas with isolate CEN517 did not found the same efficiency. Sporulation of Trichoderma was higher using parboiled rice as the substrate, compared to millet. In general terms, it was obtained $3.38 \times 10^{9}$ and $2.84 \times 10^{9}$ conidia/g for the two substrates, respectively. Some of these Trichoderma isolates may be used in development of biofungicides for biocontrol of leaf spot, especially CEN262, due to its suppressive effect on C. scoparium, high sporulation, growth promotion capacity and endophytic colonization in eucalyptus seedlings.
\end{abstract}

Keywords: eucalyptus leaf spot, Cylindrocladium scoparium, inoculum production

\section{Introduction}

The cloning mini-cutting has been adopted in most forestry companies. Although this technique is very efficient, during the rooting of the shoots, there is a pathogen incidence due to favorable environmental conditions. The mini-cuttings are kept in conditions of high humidity and mild temperatures for 20 to 25 days in the rooting. Under these conditions, it is common the occurrence of pathogenic fungi such as Botrytis cinerea, Cylindrocladium spp., Rhizoctonia solani, Pestalotiopsis sp. and Hainesia sp. (Maciel et al., 2012). In Brazil, eucalyptus leaf spot, caused by species of Cylindrocladium Morgan, are severe diseases almost always occurring causing defoliation and death in young plantations and clonal seedlings. Leaf spots result in necrosis of leaves followed by death or inhibition of plant growth. These, if used for planting, may die either by the action of the pathogen attack or by secondary pathogens (Ferreira, 1989).

Fungi of the Trichoderma genus are among the most studied organisms as antagonists, mainly from soil pathogens. Furthermore, its ability to promote plant growth is recognized in several studies (Contreras-Cornejo et al., 2009; Saba et al., 2012; El-Hassan et al., 2013), quality that has been attributed, in some cases, to the production of plant hormones, solubilization of nutrients such as phosphate, and control of pathogens (Hoyos-Carvajal et al., 2009; Carvalho et al., 2011). Another important feature presented by certain Trichoderma strains is the ability to endophytic colonization from differents plant organs (Rubini et al., 2005; Silva et al., 2006; Chaverri et al., 2011). Interestingly, the habitat associated with the plant is a dynamic environment that enables various factors exerts influence on the composition and structure of microbial communities or in interaction with the roots and other plant parts (Sanogo et al., 2002).

Considering the huge potential of Trichoderma members for use in agriculture, conservation and maintenance of natural isolates of these fungi in culture collections has been encouraged, making possible the screening of ecophysiological diversity and information on the functionality of these genomic resources such as biological 
reserve for future applications. This study aimed to explorate Trichoderma isolates kept in collection, in order to identify promising biocontrol agents for the leaf spot of eucalyptus based on the antagonism, promoting growth capacity and its ability to colonize endophytically seedlings of eucalyptus.

\section{Methods}

\subsection{Microorganisms and Culture Conditions}

Twelve strains of Trichoderma were isolated from different Brazilian agroecosystems (Table 1). Two isolates of the pathogen (CEN494 and CEN517 isolates) were obtained from eucalyptus leaves. All isolates were cultured on potato dextrose agar (PDA) supplemented with $0.01 \%$ chloramphenicol and stored in plates on agar $4{ }^{\circ} \mathrm{C}$ prior to use.

Table 1. Geographical areas of origin and Trichoderma species used in this study

\begin{tabular}{lll}
\hline Isolate code & Geographical origin/substrate & Identification \\
\hline CEN162 & Federal District/rhizosphere soil from rice & T. asperellum \\
CEN201 & Mato Grosso State/rhizosphere soil from Vochyziaceae & T.asperellum \\
CEN209 & Federal District/rhizosphere soil from copaiba & T. koningiopsis \\
CEN262 & Federal District/rhizosphere soil from cotton & T. harzianum \\
CEN492 & Origen unknown & Trichoderma sp. \\
CEN498 & Federal District/rhizosphere soil from Pinnus & Trichoderma sp. \\
CEN500 & Pernambuco State /rhizosphere soil from guava & T. erinaceum \\
CEN516 & Goiás State/rhizosphere soil from Cerrado & T. brevicompactum \\
CEN515 & Goiás State/rhizosphere soil from Cerrado & Trichoderma sp. \\
CEN518 & Pernambuco State/rhizosphere soil from guava & T. asperellum \\
CEN519 & Pernambuco State/rhizosphere soil from guava & T. asperellum \\
CEN520 & Pernambuco State/rhizosphere soil from guava & T. asperellum \\
\hline
\end{tabular}

\subsection{Volatile and Non-volatile Metabolites}

Separate plates containing PDA medium were inoculated in the centre with a 5-mm diameter mycelial disc containing C. scoparium or the different Trichoderma strains. The lids were removed, and each plate was inverted and placed on top of another plate. Each plate base was then sealed with a double layer of parafilm. The plates were incubated at $25{ }^{\circ} \mathrm{C}$ with a 12 -h photoperiod. The pathogen was grown in the upper plate to avoid interference by spores in the lower plate inoculated with the antagonists. The pathogen colony diameter was estimated when the pathogen completely covered the control plate without Trichoderma, and was converted to the percentage of inhibition in relation to the control plate. The experiment was replicated three times for each Trichoderma strain.

Mycelial growth inhibition of $S$. sclerotiorum as a result of non-volatile metabolites of Trichoderma was evaluated as described by Agrawal et al. (1977), with some minor modifications. The biocontrol agents were grown in Potato dextrose broth at $25^{\circ} \mathrm{C}$ with intermittent shaking at $150 \mathrm{rpm}$. The metabolites were collected after seven days and filtered. The sterilized filtrate was PDA medium to make a $25 \%$ concentration in Petri plates The solidified agar plates in triplicates were inoculated at the centre with a $5 \mathrm{~mm}$ diameter mycelial disc of pathogen and incubated at $25^{\circ} \mathrm{C}$ for 7 days. The Plates without filtrate served as control. The colony diameter was measured and percent inhibition of radial growth was calculated. The experiment was replicated three times for each Trichoderma strains.

\subsection{Evaluation of Trichoderma sporulation in Parboiled Rice and Millet Grain}

Three disks ( $5 \mathrm{~mm}$ diameter) were transferred of a PDA medium containing spores and mycelia of biocontrol agents to $125 \mathrm{~mL}$ flasks previously autoclaved containing $25 \mathrm{~g}$ of substrate (parboiled rice or millet) with distilled water $60 \%(\mathrm{w} / \mathrm{v})$. The flasks were incubated at photoperiod of $12 \mathrm{~h}$ at a temperature of $25^{\circ} \mathrm{C}$ for 7 or 11 days. Colonized substrate samples were processed for determining the concentration of spores per gram of substrate at 07 and 11 days with the support of a Neubauer chamber.

\subsection{Evaluation of the Suppression of Leaf Spot Caused by C. scoparium Using Trichoderma spp. as Antagonist in Eucalyptus Detached Leaves}

Ten discs of PDA cultures ( $5 \mathrm{~mm}$ diameter) of the five following selected Trichoderma spp. isolates by species in vitro assays such as greater capacity to inhibit the pathogen, and high sporulation (CEN162, CEN209, CEN262, 
CEN498, CEN500) were produced in plastic bags in parboiled rice with distilled water ( $60 \% \mathrm{w} / \mathrm{v})$, previously autoclaved and kept for 7 days at $25{ }^{\circ} \mathrm{C}$ with $12 \mathrm{~h}$ of photoperiod. After 7 days of incubation the substrate of each bag was washed with water to obtain the spore suspension which was adjusted to $10^{7}$ conidia $/ \mathrm{mL}$. To evaluate the suppression of $C$. scoparium leaf spot in detached leaves of eucalyptus, it was first induced sporulation of pathogens isolates in SG liquid medium. After 15 days of culture in shaker with rotation of 170 rpm at temperature of $27^{\circ} \mathrm{C}$, the conidia were collected, filtered and spore concentrations were adjusted to $10^{5}$ conidia/mL.

The detached leaves used in the experiments were obtained from eucalyptus mini-clonal hedges (Eucalyptus grandis $\times$ Eucalyptus urophilla) grown under greenhouse conditions without diseases. Young leaves were used, aged 10 to 15 days with their petioles featured along the stems. The leaves, previously washed with distilled water, were taken the petioles and then wrapped and moistened in cotton with sterile distilled water and then placed on filter paper, also moistened with sterile water and distributed in plastic boxes (a couple of leaves/box). The inocula were sprayed on the leaves, whereas antagonist sprays were taken immediately after spraying of pathogens. Three treatments were used for this experiment prepared in triplicate control so described: spraying with distilled water, spraying with two isolates of $C$. scoparium and spraying with the antagonist isolates. The boxes were kept at ambient temperature of $25^{\circ} \mathrm{C}$. The experiment was performed twice with three replicates per treatment. Each box represents an experimental unit. The evaluations occurred at five days of incubation according to the scale developed by Alfenas et al. (2009), ranging from 1 to $44 \%$ of leaf spot caused by the leaf pathogen.

\subsection{Effect of Trichoderma Strains in Promoting the Growth of Eucalyptus grandis $\times$ Eucalyptus urophilla Seedlings and Endophytic Colonization}

The experiment was conducted in commercial eucalyptus mini-clonal hedges system of hybrid plants. For the experiment, $100 \mathrm{~mL}$ of the suspension of each Trichoderma isolate at $10^{7}$ conidia $/ \mathrm{mL}$ was added to $30 \mathrm{~kg}$ of substrate containing carbonized rice hulls: vermiculite (1:1) supplemented with macro and micro nutrients, homogenized and placed in tubes $\left(50 \mathrm{~cm}^{3}\right)$ sterilized. The plants received two applications of suspension of $10^{7}$ conidia/mL at 30 and 45 days after planting the seeds or mini-cuttings. Controls were made with distilled water sprays. The plants at 60 days of age were conducted in the laboratory to obtain data of growth and height (considering the roots and aerial parts) or dry weight (48h of drying at $70{ }^{\circ} \mathrm{C}$ ). The experimental design was completely randomized with ten repetitions, each repetition was composed of a eucalypt seedling.

Eucalyptus plants were collected at 60 days old and disinfected surface: $2 \times$ tap water $(30 \mathrm{~s}), 1 \times 70 \%$ ethanol $(60 \mathrm{~s}), 1 \times 3 \%$ sodium hypochlorite $(4 \mathrm{~min}), 1 \times 70 \%$ ethyl alcohol $(30 \mathrm{~s})$ and tap water $3 \times(60 \mathrm{~s})$. Ten plants were collected per treatment, and four fragments of each plant were used as follows: (1) leaves were cut into discs of $5 \mathrm{~mm}$, (2) stems in fragments 3-5 mm and (3) roots fragments of 1 to $2 \mathrm{~cm}$. After treatment of plant material, they were plated on PDA and incubated at $25^{\circ} \mathrm{C}$ with a photoperiod of $12 \mathrm{~h}$ for 5 days. Three replicates were performed and repeated twice.

\subsection{Statistical Analysis}

The results were compared using analysis of variance (ANOVA) and means separation by the Tukey test ( $\alpha=$ $5 \%$ ), with SISVAR software.

\section{Results}

\subsection{Volatile and Non-volatile Metabolites}

About the volatile metabolites, the percentage mean values of mycelial inhibition exerted on CEN494 and CEN517 pathogen isolates ranged from $7.4 \%$ to $37.7 \%$ and from $11.1 \%$ to $33.3 \%$, respectively. In terms of average diameter of mycelial growth, six of the 12 isolates differed significantly from the control, however, did not differ among themselves in confrontation with the CEN494 isolate. In relation to the CEN517 isolate, all Trichoderma isolates differed from the control (Table 2).

For the tests of non-volatile metabolites, variation in mean percentage of mycelial inhibition was observed from $4.4 \%$ to $42.2 \%$ and from $4.3 \%$ to $26.6 \%$ for CEN494 and CEN517 isolates, respectively. In terms of average diameter of inhibition, six of the 12 isolates differed from the control, however, four strains (CEN262, CEN498, CEN500 and CEN515) highlights inhibiting the mycelial growth of the pathogen CEN494. In relation to CEN517 isolate pathogen, although six Trichoderma strains differed from the control, there was no statistically significant difference between all isolates in mycelial pathogen inhibition (Table 2). 
Table 2. Inhibition rate of Trichoderma spp. face to two isolates of Cyllindrocladium scoparium in bioactivity of non-volatile and volatile metabolites of antagonist isolates

\begin{tabular}{|c|c|c|c|c|c|c|c|c|}
\hline \multirow{3}{*}{ Isolates } & \multicolumn{4}{|c|}{ C. scoparium CEN494 } & \multicolumn{4}{|c|}{ C. scoparium CEN517 } \\
\hline & \multicolumn{2}{|c|}{ NVM } & \multicolumn{2}{|c|}{ VM } & \multicolumn{2}{|c|}{ NVM } & \multicolumn{2}{|c|}{$\mathrm{VM}$} \\
\hline & $\mathrm{AD}$ & $\mathrm{I}(\%)$ & $\mathrm{AD}$ & $\mathrm{I}(\%)$ & $\mathrm{AD}$ & $\mathrm{I}(\%)$ & $\mathrm{AD}$ & I $(\%)$ \\
\hline CEN162 & $7.0 \mathrm{abc}$ & $22.2 \%$ & $5.66 \mathrm{a}$ & $37.7 \%$ & $6.66 \mathrm{a}$ & 26.6 & $6.33 \mathrm{ab}$ & 29.6 \\
\hline CEN201 & $8.0 \mathrm{bc}$ & $11.1 \%$ & $7.66 \mathrm{bc}$ & $14.8 \%$ & $7.66 \mathrm{abcd}$ & 14.8 & $7.66 \mathrm{bc}$ & 14.8 \\
\hline CEN209 & $6.0 \mathrm{ab}$ & $33.3 \%$ & $6.33 \mathrm{ab}$ & $29.6 \%$ & $6.66 \mathrm{a}$ & 26.6 & $6.00 \mathrm{a}$ & 33.3 \\
\hline CEN262 & $5.3 \mathrm{a}$ & $40.7 \%$ & $5.66 \mathrm{a}$ & $37.7 \%$ & $7.00 \mathrm{ab}$ & 22.2 & $6.33 \mathrm{ab}$ & 29.6 \\
\hline CEN492 & $7.8 \mathrm{bc}$ & $13.3 \%$ & $7.66 \mathrm{bc}$ & $14.8 \%$ & $8.66 \mathrm{~cd}$ & 4.3 & $7.00 \mathrm{abc}$ & 22.2 \\
\hline CEN498 & $5.2 \mathrm{a}$ & $42.2 \%$ & $5.33 \mathrm{a}$ & $40.7 \%$ & $7.00 \mathrm{ab}$ & 22.2 & $6.33 \mathrm{ab}$ & 29.6 \\
\hline CEN500 & $5.4 \mathrm{a}$ & $40.0 \%$ & $5.66 \mathrm{a}$ & $37.7 \%$ & $7.00 \mathrm{ab}$ & 22.2 & $6.00 \mathrm{a}$ & 33.3 \\
\hline CEN515 & $5.66 \mathrm{a}$ & $37.7 \%$ & $7.0 \mathrm{abc}$ & $22.2 \%$ & $7.66 \mathrm{abcd}$ & 14.8 & $7.00 \mathrm{abc}$ & 22.2 \\
\hline CEN516 & $6.7 \mathrm{ab}$ & $25.5 \%$ & $6.33 \mathrm{ab}$ & $29.6 \%$ & $7.33 \mathrm{abc}$ & 18.5 & $7.33 \mathrm{abc}$ & 18.5 \\
\hline CEN518 & $8.0 \mathrm{bc}$ & $11.1 \%$ & $7.66 \mathrm{bc}$ & $14.8 \%$ & $8.00 \mathrm{abcd}$ & 11.1 & $7.33 \mathrm{abc}$ & 18.5 \\
\hline CEN519 & $8.6 \mathrm{c}$ & $4.4 \%$ & $8,33 \mathrm{c}$ & $7.4 \%$ & $7.66 \mathrm{abcd}$ & 14.8 & $7.00 \mathrm{abc}$ & 22.2 \\
\hline CEN520 & $8.0 \mathrm{bc}$ & $11.1 \%$ & $8.00 \mathrm{bc}$ & $11.1 \%$ & $8.33 \mathrm{abcd}$ & 7.4 & $8.00 \mathrm{c}$ & 11.1 \\
\hline Control & $9.0 \mathrm{c}$ & - & $9.0 \mathrm{c}$ & - & $9.0 \mathrm{~d}$ & - & $9.0 \mathrm{~d}$ & - \\
\hline $\mathrm{CV}(\%)$ & 9.3 & - & 9.3 & - & $6^{-1-}$ & - & 8 & - \\
\hline
\end{tabular}

Note. AD: Average Diameter (cm); I: Inhibition (\%); NVM: Non-Volatiles Metabolites; VM: Volatile Metabolites. Means followed by the same letter do not differ by the Tukey test $(\mathrm{P} \leq 0.05)$.

\subsection{Evaluation of Trichoderma sporulation in Parboiled Rice and Millet Grain}

The sporulation of Trichoderma isolates in two solid substrates (grain parboiled rice and millet), the higher rates of sporulation of Trichoderma was obtained in parboiled rice with average values of sporulation were $3.38 \times 10^{9}$ and $2.84 \times 10^{9}$ conidia/g for millet. In general, there was greater number of spores in 11 days of incubation for both substrates, which were numbered $3.37 \times 10^{9}$ conidia/g, while the seven days, the value was $2.85 \times 10^{9}$ conidia/g. Evaluating only the data sporulation with 11 days of incubation of Trichoderma, higher levels of sporulation of the strains CEN162, CEN201 and CEN262 were observed with variation of $4.5 \times 10^{9}$ to $7.7 \times 10^{9}$ conidia/g, and CEN162 and CEN201 strains sporulated best in parboiled rice and CEN262 in millet. The CEN209, CEN500, CEN515, CEN516, CEN518 and CEN519 isolates had the lowest rates of spore production in millet (Table 3).

Table 3. Conidia number of Trichoderma on two solids substrates at 11 days of incubation

\begin{tabular}{lll}
\hline Isolates & Parboiled rice & Millet \\
\hline CEN162 & $4.5 \mathrm{Aa}$ & $2.8 \mathrm{Ba}$ \\
CEN201 & $4.5 \mathrm{Aa}$ & $2.0 \mathrm{Bd}$ \\
CEN209 & $1.5 \mathrm{Acde}$ & $1.1 \mathrm{Ba}$ \\
CEN262 & $5.0 \mathrm{Ba}$ & $7.7 \mathrm{Aa}$ \\
CEN492 & $3.3 \mathrm{Ab}$ & $3.3 \mathrm{Ac}$ \\
CEN498 & $3.3 \mathrm{Bb}$ & $7.0 \mathrm{Ab}$ \\
CEN500 & $1.3 \mathrm{Ade}$ & $1.5 \mathrm{Aef}$ \\
CEN515 & $1.1 \mathrm{Bde}$ & $3.3 \mathrm{Ac}$ \\
CEN516 & $1.0 \mathrm{Ae}$ & $1.0 \mathrm{Af}$ \\
CEN518 & $6.0 \mathrm{Acd}$ & $1.6 \mathrm{Adef}$ \\
CEN519 & $3.8 \mathrm{Ab}$ & $1.6 \mathrm{Bdef}$ \\
CEN520 & $2.1 \mathrm{Ac}$ & $2.2 \mathrm{Ad}$ \\
CV $(\%)$ & 4.37 & 4.57 \\
\hline
\end{tabular}

Note. Average conidia number $\left(\times 10^{9}\right.$ spores $\left.\mathrm{g}^{-1}\right)$. Means followed by the same letter uppercase (vertical) and lowercase (horizontal) do not differ by Tukey test $(\mathrm{P} \leq 0.05)$. 


\subsection{Evaluation of the Suppression of Leaf Spot Caused by C. scoparium Using Trichoderma spp. as Antagonist in Eucalyptus Detached Leaves}

For the experiments on detached leaves and promoting growth in seedlings of eucalyptus, five different species of Trichoderma showed a high level of pathogen control in vitro and high sporulation rate. Thus, the isolates were chosen for the greenhouse and in mini cuttings of Eucalyptus: CEN162, CEN209, CEN262, CEN498 and CEN500.

The experiment to evaluate the suppression of leaf spot caused by C. scoparium conducted with detached leaves of eucalyptus (Table 4) was observed high efficiency of the five antagonists tested against the pathogen CEN494, since all abolished the disease. The mean values of severity of leaf spot did not exceed the level of $1 \%$ of the scale proposed by Alfenas et al. (2009). The exception was observed with CEN498 isolate, for which these values were up 4\%. Since the treatments of Trichoderma isolates against the pathogen CEN517 isolate, the disease severity in leaves treated with CEN162, CEN262 and CEN500 strains was 15\%. To the CEN209 strain, the average disease severity was $31 \%$, exceeding the control that showed the same severity $(24 \%)$ of treatment with the CEN498 isolate.

Table 4. Effect of Trichoderma isolates in the suppression of leaf spot of C. scoparium in detached leaves of eucalyptus

\begin{tabular}{lll}
\hline \multirow{2}{*}{ Isolates } & \multicolumn{2}{c}{ C. scoparium } \\
\cline { 2 - 3 } & CEN 494 (\%) & CEN 517 (\%) \\
\hline CEN162 & 1 & 15 \\
CEN209 & 1 & 31 \\
CEN262 & 0 & 15 \\
CEN498 & 4 & 24 \\
CEN500 & 1 & 15 \\
Control & 24 & 24 \\
\hline
\end{tabular}

Note. Evaluation of severity according to diagrammatic scale ranging from 1 to $44 \%$ (Alfenas et al., 2009).

\subsection{Effect of Trichoderma Strains in Promoting the Growth of Eucalyptus grandis $\times$ Eucalyptus urophilla Seedlings and Endophytic Colonization}

The experiment evaluation of Trichoderma as growth promoter conducted with clonal seedling (Table 5), CEN162 and CEN262 strains showed the highest percentage of average with increments of the total dry weight of plants between $123 \%$ and $139 \%$, respectively. Plus, to the CEN209 and CEN498 strains, the average increased in total dry mass values was between $57 \%$ and $65 \%$, respectively. The CEN500 strain did not differ significantly of control. In terms of developing shoots, the CEN262 strain differed significantly of all isolates, which resulted in a mean increase in height of $43 \%$ compared to the control. Plants treated with CEN162, CEN209 and CEN498 strains showed an increase in height about $22.8 \%$ more than the control, which did not differ significantly from CEN500 strain.

Table 5. Growth promotion of Eucalyptus grandis $\times$ E. urophylla seedlings using Trichoderma spp. isolates (Luziânia GO)

\begin{tabular}{llll}
\hline \multirow{2}{*}{ Trichoderma spp. isolates } & \multicolumn{2}{c}{ Dry mass } & Height \\
\cline { 2 - 4 } & Root & \multicolumn{2}{c}{ Aerial part } \\
\hline CEN162 & $0.52 \mathrm{a}$ & $1.54 \mathrm{a}$ & $38.8 \mathrm{~b}$ \\
CEN209 & $0.35 \mathrm{bc}$ & $1.11 \mathrm{bc}$ & $37.9 \mathrm{~b}$ \\
CEN262 & $0.54 \mathrm{a}$ & $1.66 \mathrm{a}$ & $44.2 \mathrm{a}$ \\
CEN498 & $0.36 \mathrm{~b}$ & $1.16 \mathrm{~b}$ & $36.8 \mathrm{~b}$ \\
CEN500 & $0.28 \mathrm{bc}$ & $0.84 \mathrm{~cd}$ & $32.7 \mathrm{c}$ \\
Testemunha & $0.22 \mathrm{c}$ & $0.70 \mathrm{~d}$ & $30.8 \mathrm{c}$ \\
CV $(\%)$ & 29.1 & 26.20 & 17.35 \\
\hline
\end{tabular}

Note. Means followed by the same letter do not differ by the Tukey test $(\mathrm{P} \leq 0.05)$. 
Concerning the endophytic colonization, attempts to localize the Trichoderma in clonal eucalyptus seedlings revealed the presence of the antagonist only in the roots that were treated with CEN162, CEN262 and CEN498 strains.

\section{Discussion}

In this study, an in vitro selection of Trichoderma strains for growth promotion in eucalyptus seedlings were performed as well as its endophytic behavior, thus, to check the potential of becoming a commercial biological control agent against $C$. scoparium. Selection of Trichoderma for biological control begins by deleting ineffective strains against the pathogen using in vitro experiments and later in field experiments. Such selected antagonists, preferably should promote growth and protection of plants against biotic and abiotic agents and providing greater productivity in target plants (Lucon et al., 2009).

Regarding to the mechanisms of action of Trichoderma on the pathogens, we can mention that antibiosis is the interaction of the antagonist which release volatile or non-volatile metabolites capable of inhibiting or preventing the development of other target microorganisms (Benítez et al., 2004; Velusamy et al., 2006; Amorim et al., 2011). In the present work, it was possible to select strains with high potential for growth inhibition of $C$. scoparium hyphae by volatile and non-volatile metabolites with values around 37-40 \% for CEN262, CEN498 and CEN500 strains. The action of these compounds in suppressing mycelial growth of fungi complies with Castillo et al. (2011), who observed $100 \%$ of mycelial inhibition of $S$. sclerotiorum by volatile metabolites with five strains of $T$. asperellum and two of T. longibrachiatum. Lopes et al. (2012) also supports this work by presenting the mycelial inhibition of pathogen $S$. sclerotiorum by non-volatile metabolites at levels above $50 \%$.

The availability, cost, efficiency and practicality are important to consider in the choice of substrate for cultivation biocontrol agent, especially when the aim is to develop a biofungicide. Cereal grains provide these advantages, therefore are the most used. They are readily biodegradable, facilitating applications in the field, in addition, exhibit facility for quantitation of the produced propagules (Jackson, 1997; Fortes et al., 2007). Although fungi sporulation is an isolate-dependent feature (Carvalho et al., 2008), an important factor in the selection of Trichoderma strains is the mass production of a standard substrate for the cultivation species, which the knowledge of appropriate culture conditions that enable this species or strain to obtain high growth and sporulation for use in biological formulations (Khalil et al., 1985). Thus, in this work were chosen five strains of different species for testing against leaf spot by $C$. scoparim and promoting growth in seedlings of eucalyptus aiming the selection of Trichoderma. Cavalcante et al. (2008) evaluated three different substrates aiming higher rates of sporulation of $T$. harzianum and $T$. viride concludes that the bran wheat moistened with water was the greatest to induce the sporulation. Sargin et al. (2013) tested products with little expression in agriculture and also noted that bran wheat was a good inducer of sporulation of Trichoderma.

Tests with detached leaves have proved useful in determining the potential biocontrol agents as described in this work for CEN162, CEN262 and CEN500 strains for control of leaf spot on eucalyptus by C. scoparium in detached leaves. A possible explanation for this result lies in the fact that on the phylosphere, the quick vegetal tissue colonization seems to be among the most important factors (Grigoletti Júnior et al., 2000). Besides, according to Maciel et al. (2012) Trichoderma strains were able to reduce the damage caused by C. candelabrum in eucalyptus leaves.

Zaldua and Sanfuentes (2010) found rooting promotion of Eucalyptus globulus mini-cuttings when treated with Trichoderma strains and Clonostachys, then attributed this effect to the ability of these fungus to increase tolerance to different abiotic stress and pathogen control, directly and indirectly influencing the promotion and development of the plant. The growth promotion can be induced by Trichoderma expressed in several types of plants. Zhang et al. (2013), and Silva et al. (2011) reported that nineteen strains Trichoderma promoted growth of the cucumber plants. These authors showed that a mechanism of the growth promotion was the production of acid indole acetic by the Trichoderma strains. Harman (2000) showed that Trichoderma (T-22) in soil applications increased the rate of growth of the tomato. This author postulates that this effect occurred probably because of displacement and control of deleterious root microflora and, in the present study, was reported colonization of root hairs by Trichoderma or even direct effects on plants through unidentified metabolites produced by antagonistic.

Silva et al. (2012) showed that two strains of Trichoderma as a potential growth promoters which can be used in agriculture to increase the rice plants, this fact related by the authors demonstrate the phosphate solubilization by the Trichoderma and production of metabolites that provide plant growth promoting. Hermosa et al. (2012) postulated that certain Trichoderma strains have beneficial effects in the gain on plant growth promotion and provide resistance against biotic and abiotic conditions. The group attributes this fact to the phosphate 
solubilization and production of indol acetic acid acting directly on the plant and the production of secondary metabolites in the control of pathogens that could depress the growth of the plants. This affirmation confirms the results reported by Alwhibi et al. (2017), who proved that T. harzianum is useful in mitigating the negative effects of drought stress. However, Nieto-Jacobo et al. (2017) described that growth promotion is dependent on the organisms interacting and is also influenced by environmental conditions where the interaction occurs, just as it happened to Gonzalez and Fuentes (2016) that verified negative effects on Manihot esculenta and Oryza sativa and positive effects on Lactuta sativa L. using T. harzianum.

According Hoyos-Carvajal et al. (2009), the ability of Trichoderma to colonize plant roots are more associated with the event in promoting growth than the actual production of phytohormones by antagonist. Thus, it has become extremely important for this work to evaluate endophytic colonization. There are many studies that have been reporting Trichoderma colonizing the roots of eucalyptus (Sbravatti Junior et al., 2013, Azevedo et al., 2017). In the present study, the CEN262 strain showed the best growth of eucalyptus plants in seedlings experiment (Table 5), and positive results of endophytic colonization of eucalyptus roots. Analogously, in studies with bean seedlings after treatment with Trichoderma, Hoyos-Carvajal et al. (2009) verified that colonization in the roots were more related to the plant growth promotion than other properties such as phosphate solubilization and production of phytohormones. Similarly, Carvalho et al. (2011) also found differences among strains of $T$. harzianum as their ability to colonize the rhizosphere of bean plants at 10 days of cultivation; such variation was $37-92 \%$ and $15-81 \%$ in the initial and final $5 \mathrm{~cm}$ of roots, respectively. In the same study, the authors found that colonization of roots were strongly related to the ability of the strains of $T$. harzianum to promote plant growth of common bean.

\section{Conclusion}

It is concluded that the study characterized Trichoderma strains for development of biotechnological tools in combating the eucalyptus leaf spot, which affects seedling production, and promotion of growth to better quality and health of seedlings inoculated with Trichoderma.

\section{References}

Agrawal, S. C., Khare, M. N., \& Agrawal, P. S. (1977). Biological control of Sclerotium rolfsii causing collar rot of lentil. Indian Phytopathology, 30(2), 176-179.

Alfenas, A. C., Zauza, E. A. V., Mafia, R. G., \& Assis, T. F. (2009). Clonagem e doenças do eucalipto (p. 500). Viçosa: Editora UFV.

Alwhibi, M. S., Hashem, A., Abd Allah, E. F., Alqarawi, A. A., Soliman, D. W. K., Wirth, S., \& Egamberdieva, D. (2017). Increased resistance of drought by Trichoderma harzianum fungal treatment correlates with increased secondary metabolites and proline content. Journal of Integrative Agriculture, 16(8), 1751-1757. https://doi.org/10.1016/S2095-3119(17)61695-2

Amorim, L., Rezende, J. A. M., \& Bergamin Filho, A. (2011). Manual de Fitopatologia (4th ed., pp. 383-387). Piracicaba: Agronômica Ceres.

Azevedo, G. B., Novaes, Q. S., Azevedo, G. T. O. S., Silva, H. F., Sobrinho, G. G. R., \& Novaes, A. B. (2017). Efeito de Trichoderma spp. no crescimento de mudas clonais de Eucalyptus camaldulensis. Scientia Forestalis, 45(114), 343-352. https://doi.org/10.18671/scifor.v45n114.10

Benítez, T., Rincón, A. M., Limón, M. C., \& Codón, A. C. (2004). Biocontrol mechanisms of Trichoderma strains. International Microbiology, 7(4), 249-260.

Carvalho, D. D. C., Alves, E., Batista, T. R. S., Camargos, R. B., \& Lopes, E. A. G. L. (2008). Comparison of methodologies for conidia production by Alternaria alternata from citrus. Brazilian Journal of Microbiology, 39(4), 792-798. https://doi.org/10.1590/S1517-83822008000400036

Carvalho, D. D. C., Mello, S. C. M., Lobo Júnior, M., \& Geraldine, A. M. (2011). Biocontrol of seed pathogens and growth promotion of common bean seedlings by Trichoderma harzianum. Pesquisa Agropecuária Brasileira, 46(8), 822-828. https://doi.org/10.1590/S0100-204X2011000800006

Castillo, F. D. H., Padilla, A. M. B., Morales, G. G., Siller, M. C., Herrera, R. R., Gonzales, C. A. N., \& Reyes, F. C. (2011). In Vitro Antagonist Action of Trichoderma Strains against Sclerotinia sclerotiorum and Sclerotium cepivorum. American Journal of Agricultural and Biological Sciences, 6(3), 410-417. https://doi.org/10.3844/ajabssp.2011.410.417 
Cavalcante, R. S., Lima, H. L. S., Pinto, G. A. S., Gava, C. A. T., \& Rodrigues, S. (2008). Effect of Moisture on Trichoderma Conidia Production on Corn and Wheat Bran by Solid State Fermentation. Food Bioprocess Technology, 1(1), 100-104. https://doi.org/10.1007/s11947-007-0034-x

Chaverri, P., Gazis, R. O., \& Samuels, G. J. (2011). Trichoderma amazonicum, a new endophytic species on Hevea brasiliensis and H. guianensis from the Amazon basin. Mycologia, 103(1), 139-151. https://doi.org/ 10.3852/10-078

Contreras-Cornejo, H. A., Macias-Rodriguez, L., Cortes-Penagos, C., \& Lopez-Bucio, J. (2009). Trichoderma virens, a plant beneficial fungus, enhances biomass production and promotes lateral root growth through an auxin dependent mechanism in Arabidopsis. Plant Physiology, 149(3), 1579-1592. https://doi.org/10.1104/ pp.108.130369

El-Hassan, S. A., Gowen, S. R., \& Pembroke, B. (2013). Use of Trichoderma hamatum for biocontrol of lentil vascular wilt disease: Efficacy, mechanisms of interaction and future prospects. Journal of Plant Protection Research, 53(1), 12-26. https://doi.org/10.2478/jppr-2013-0002

Ferreira, F. A. (1989). Patologia florestal: Principais doenças florestais do Brasil (p. 570). SIF, Viçosa, Minas Gerais.

Fortes, F. O., Silva, A. C. F., Almança, M. A. K., \& Tedesco, S. B. (2007). Promoção de enraizamento de microestacas de um clone de Eucalyptus sp. por Trichoderma spp. Revista Árvore, 31(2), 221-228. https://doi.org/10.1590/S0100-67622007000200004

Gonzalez, F. H., \& Fuentes, M. N. (2017). Mecanismo de acción de cinco microorganismos promotores de crecimiento vegetal. Revista Ciência Agronômica, 34(1), 17-31. https://doi.org/10.22267/rcia.173401.60

Grigoletti Júnior, A., Santos, A. F., \& Auer, C. G. (2000). Perspectivas do uso do controle biológico contra doenças florestais. Floresta, 30(1/2), 155-165. https://doi.org/10.5380/rf.v30i12.2362

Harman, G. E. (2000). Myths and dogmas of biocontrol changes in perceptions derived from research on Trichoderma harzianum T-22. Plant Disease, 84(4), 377-393. https://doi.org/10.1094/PDIS.2000.84.4.377

Hermosa, R., Viterbo, A., Chet, I., \& Monte, E. (2012). Plant-beneficial effects of Trichoderma and of its Genes. Microbiology, 158(1), 17-25. https://doi.org/10.1099/mic.0.052274-0

Hoyos-Carvajal, L., Orduz, S., \& Bissett, J. (2009). Growth stimulation in bean (Phaseolus vulgaris L.) by Trichoderma. Biological Control, 51(3), 409-416. https://doi.org/10.1016/j.biocontrol.2009.07.018

Jackson, M. A. (1997). Optimizing nutritional conditions for the liquid culture production of effective fungal biological control agents. Journal of Industrial Microbiology \& Biotechnology, 19(3), 180-187. https://doi.org/10.1038/sj.jim.2900426

Khalil, S. K., Shah, M. A., \& Naeem, M. (1985). Laboratory studies on the compatibility of the entomopathogenic fungus Verticillium lecanii with certain pesticides. Agriculture, Ecosystems \& Environment, 13(3/4), 329-334. https://doi.org/10.1016/0167-8809(85)90021-0

Lopes, F. A. C., Steindorff, A. S., Geraldine, A. M., Brandão, R. S., Monteiro, V. N., Lobo Junior, M., ... Silva, R. N. (2012). Biochemical and metabolic profiles of Trichoderma strains isolated from common bean crops in the Brazilian Cerrado, and potential antagonism against Sclerotinia sclerotiorum. Fungal Biology, 116(7), 815-824. https://doi.org/10.1016/j.funbio.2012.04.015

Lucon, C. M. M., Koike, C. M., Ishikawa, A. I., Patrício, F. R. A., \& Harakava, R. (2009). Bioprospecção de isolados de Trichoderma spp. para o controle de Rhizoctonia solani na produção de mudas de pepino. Pesquisa Agropecuária Brasileira, 44(3), 225-232. https://doi.org/10.1590/S0100-204X2009000300002

Maciel, C. G., Lazarotto, M., Mezzomo, R., Poletto, I., Muniz, M. F. B., \& Lippert, D. B. (2012). Trichoderma spp. no biocontrole de Cylindrocladium candelabrum em mudas de Eucalyptus saligna. Revista Árvore, 36(5), 825-832. https://doi.org/10.1590/S0100-67622012000500004

Nieto-Jacobo, M. F., Steyaert, J. M., Salazar-Badillo, F. B., Nguyen, D. V., Rostás, M., Braithwaite, M., ... Mendoza-Mendoza, A. (2017). Environmental Growth Conditions of Trichoderma spp. Affects Indole Acetic Acid Derivatives, Volatile Organic Compounds, and Plant Growth Promotion. Frontiers in Plant Science, 8, 102. https://doi.org/10.3389/fpls.2017.00102

Rubini, M. R., Ribeiro, R. T. S., Pomella, A. W. V., Maki, C. S., Araújo, W. L., Santos, D. R., \& Azevedo, J. L. (2005). Diversity of endophytic fungal community of cacao (Theobroma cacao L.) and biological control of 
Crinipellis perniciosa, causal agent of Witches' Broom Disease. International Journal of Biological Sciences, 1(1), 24-33. https://doi.org/10.7150/ijbs.1.24

Saba, H., Vibhash, D., Manisha, M., Prashant, K. S., Farhan, H., \& Tauseef, A. (2012). Trichoderma-A promising plant growth stimulator and biocontrol agent. Mycosphere, 3(4), 524-531. https://doi.org/ 10.5943/mycosphere/3/4/14

Sanogo, S., Pomellia, A., Hebbar, P. K., Bailey, B., Costa, J. C. B., Samuels, G. J., \& Lumsden, R. D. (2002). Production and germination of conidia of Trichoderma stromaticum, a mycoparasite of Crinipelis perniciosa on cacao. Phytopatology, 92(10), 1032-1037. https://doi.org/10.1094/PHYTO.2002.92.10.1032

Sargin, S., Gezgin, Y., Eltem, R., \& Vardar, F. (2013). Micropropagule production from Trichoderma harzianum EGE-K38 using solid-state fermentation and a comparative study for drying methods. Turkish Journal of Biology, 37, 139-146. https://doi.org/10.3906/biy-1206-32

Sbravatti Júnior, J. A., Auer, C. G., Pimentel, I. C., Santos, A. F., \& Schultz, B. (2013). Seleção in vitro de fungos endofíticos para o controle biológico de Botrytis cinerea em Eucalyptus benthamii. Floresta, 43(1), 145-152. https://doi.org/10.5380/rf.v43i1.26265

Silva, J. C, Torres, D. B., Lustosa, D. C., Filippi, M. C. C., \& Silva, G. B. (2012). Rice sheath blight biocontrol and growth promotion by Trichoderma isolates from the Amazon. Revista de la Facultad de Ciencias Agrarias, 55(4), 243-250. https://doi.org/10.4322/rca.2012.078

Silva, R. L. O., Luz, J. S., Silveira, E. B., \& Cavalcante, U. M. T. (2006). Fungos endofíticos em Annona spp. isolamento, caracterização enzimática e promoção do crescimento em mudas de pinha. Acta Botanica Brasilica, 20(3), 649-655. https://doi.org/10.1590/S0102-33062006000300015

Silva, V. N., Guzzo, S. D., Lucon, C. M. M., \& Harakava, R. (2011). Promoção de crescimento e indução de resistência à antracnose por Trichoderma spp. em pepineiro. Pesquisa Agropecuária Brasileira, 46(12), 1609-1618. https://doi.org/10.1590/S0100-204X2011001200005

Velusamy, P., Immanuel, J. E., Gnanamanickam, S. S., \& Thomashow, L. (2006). Biological control of rice bacterial blight by plant-associated bacteria producing 2,4-diacetylphloroglucinol. Canadian Journal of Microbiology, 52(1), 56-65. https://doi.org/10.1139/w05-106

Zaldua, S., \& Sanfuentes, E. (2010). Control of Botrytis cinerea in Eucalyptus globulus mini-cuttings using Clonostachys and Trichoderma strains. Chilean Journal of Agricultural Research, 70(4), 576-582. https://doi.org/10.4067/S0718-58392010000400007.

Zhang, F., Yuan, J., Yang, X., Cui, Y., Chen, L., Ran, W., \& Shen, Q. (2013). Putative Trichoderma harzianum mutant promotes cucumber growth by enhanced production of indole acetic acid and plant colonization. Plant Soil, 368(1/2), 433-444. https://doi.org/10.1007/s11104-012-1519-6

\section{Copyrights}

Copyright for this article is retained by the author (s), with first publication rights granted to the journal.

This is an open-access article distributed under the terms and conditions of the Creative Commons Attribution license (http://creativecommons.org/licenses/by/4.0/). 